\title{
Assessment of energy saving in residential buildings using energy efficiency measures under Cairo climatic conditions
}

\author{
Somia Nafeaa ${ }^{\text {a }}$, Ayman Mohamed ${ }^{\mathrm{a}}$, M. Fatouh ${ }^{\mathrm{a}, \mathrm{b}}$ \\ a. Mechanical Power Engineering Department, Faculty of Engineering at El-Mattaria, \\ Helwan University, Masaken El-Helmia P.O., Cairo 11718, Egypt. \\ b. High Institute for Engineering and Technology-Obour, k21 Cairo/Belbies Rd, Egypt.
}

\begin{abstract}
This paper investigates the residential building energy needs in Egypt. Firstly, the energy needs of residential building are evaluated in compliance with Energy Efficiency Residential Building Code as a base case. Then, Energy Efficiency Measures (EEMs) defined as measures that reduce energy consumption whilst maintaining the same or better indoor climate conditions are implemented as a modified case using building simulation technique. The considered EEMs include adding thermal insulation to the exterior walls, adding external shading, using lighting fixture with high efficacy and using window glazing type with high thermal and radiation characteristic. Finally, a comparison between the base and modified cases is made.The reported results showed that the thermal cooling demand, heating demand and total electricity demand of the base case are $130 \mathrm{kWh} / \mathrm{m}^{2} . \mathrm{a}, 6.5 \mathrm{kWh} / \mathrm{m}^{2} \mathrm{a}$ and 114 $\mathrm{kWh} / \mathrm{m}^{2}$.a, respectively. It is found that as the overall heat transfer coefficient of external wall decreases from $1.7 \mathrm{~W} / \mathrm{m}^{2} \mathrm{~K}$ to $0.58 \mathrm{~W} / \mathrm{m}^{2} \mathrm{~K}$ causes the cooling and heating demands to decrease by $7 \%$ and $60 \%$, respectively. Adding shading with a projection factor of 0.9 for all external windows decreases the cooling demands by $13 \%$. Using double glazing decreases the cooling and heating demands by $14 \%$ and $30 \%$, respectively. Installing LED lighting type reduces the annual space cooling demand and electricity consumption by $17 \%$ and $26 \%$, respectively. The values of each EEM which are the lowest energy needs, combining to get the optimized case in which the cooling demand, total electricity and the heating demand decrease by $34 \%, 17 \%$ and $11 \%$ respectively.
\end{abstract}




\subsection{INTRODUCTION}

Buildings over the world consumes around $40 \%$ of the world's total energy consumption [1]. The delivered energy consumption in the buildings worldwide increases annually by an average of $1.5 \%$ from 2012 to 2040 as reported in International Energy Outlook 2016[2]. In Egypt, the residential building consumes around $51 \%$ of the total electricity supplied to the grid during 2016/2017 [3] as shown in Fig.1

Implementing energy saving strategies is a pillar of "the Sustainable Development strategy, Egyptian Vision 2030. Energy Efficiency Measures (EEMs) can be implemented to achieve energy saving in the building sector. There are many strategies of building design to enhance the energy performance and reduce the energy consumption by implementing EEMs [4-5]. Comparison between different international building codes were reported in literature [6-8]. It was found that LEED, international green construction code (IGCC) and ASHARE have the same number of points of concerning materials category. Both IGCC and ASHRAE standards were recommended to be used for the design with high performance buildings while the LEED has got the highest points in social and economic aspects. In Egypt, Energy Efficiency Building Codes [9- 10] deal with the energy performance requirements of residential and nonresidential buildings.

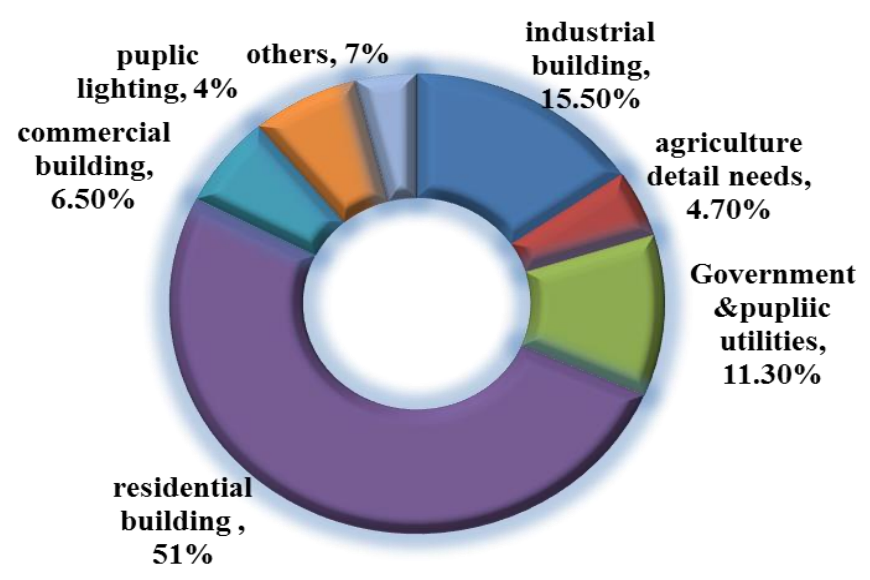

Fig.1 Total electricity in Egypt during 2016-2017 [3] 
Optimizing the building envelope elements includes the exterior wall insulation, roof insulation, window area, window glazing, window shading and thermal mass as improvement of the energy performance in residential buildings [1, 11]. They reported that implementing energy efficiency measures as thickness of the exterior wall insulation layer can save up to $842 \mathrm{MW}$ of peak demand energy, and 2190 kilotonnes /year reduction of $\mathrm{CO}_{2}$ emission. This is equivalent to 3.37TWh of electricity consumption compared to the base case. Various investigations [11,12] presented increasing the energy efficiency in buildings by changing the overall heat transfer coefficient of thermal roof and exterior wall insulation. The increasing the thickness of the insulation layer of exterior wall insulation and using better material, reducing the heating and cooling demands.

The influence of variation in the shading projection factor on building energy consumption are carried out by Alghoul [13]. Their results showed that adding shading for a building reduction the cooling loads and energy savings. The influence of variation of windows shading with low-transmittance characteristics of glazing is predicted in [14]. It's found that the increasing of window shading reduced the cooling load from $26 \%$ to $31 \%$ compared to base case.

In Raslan [15] classified the residential building and input data into five blocks as high income high rise, low income high rise, low income low rise, high income villa and rural house. Marzouk and Metawie [16] Optimized the Low income housing as one of most important housing in Egypt. Several building simulation tools were used such as Energy-plus $[13,17,18,19]$, eQUEST which is the acronym of the Quick

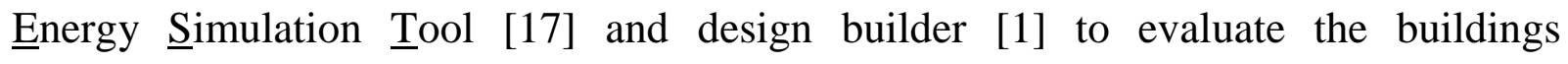
performance. The integrated tool of Open Studio and Energy-plus as the building simulation tool was used in various investigations $[2,3,6,10,11,20]$. Egyptian code for the residential building has been issued in 2006 [4]. This code describes three different paths for the residential buildings. The first path is the descriptive path where the limitation of the thermal properties of envelope elements, air infiltration rates, natural ventilation rates., artificial fixture lighting according space area should be followed. 
The second path is the trade-off path where the overall thermal transfer value for the envelope has do not exceed than the code value. The third path is the whole building performance assessment using the building simulation tool. The third path doesn't indicate any limitation values for the building energy needs.

Therefore, the objective of this research is to assess the building energy needs of the residential building following the code descriptive path (2). Also, assessing the energy saving potential in result of implementing some considered Energy Efficiency Measures.

\subsection{Research Methodology}

In the present work, a low-income high-rise building is selected as a residential building to be investigated. The selected low-income high rise building has characteristic in compliance with the Energy Efficiency for Residential Building Code [9]. This building consists of 8 stores, each store has 4 apartments. Each story has the floor area of $386 \mathrm{~m}^{2}$. Each apartment has floor area of $90 \mathrm{~m}^{2}$ and height of $3 \mathrm{~m}$ as shown in Fig .2The apartment is divided into 6 spaces; namely two bed room, reception, kitchen, bath room and hall as shown in Fig 2. The air conditioning spaces are the bed room and reception, which represent $72.5 \%$ of the total apartment area. The un-air conditioning spaces are bath room, kitchen, vertical circulation space and halls, which represent $27.5 \%$ of the total apartment area. 


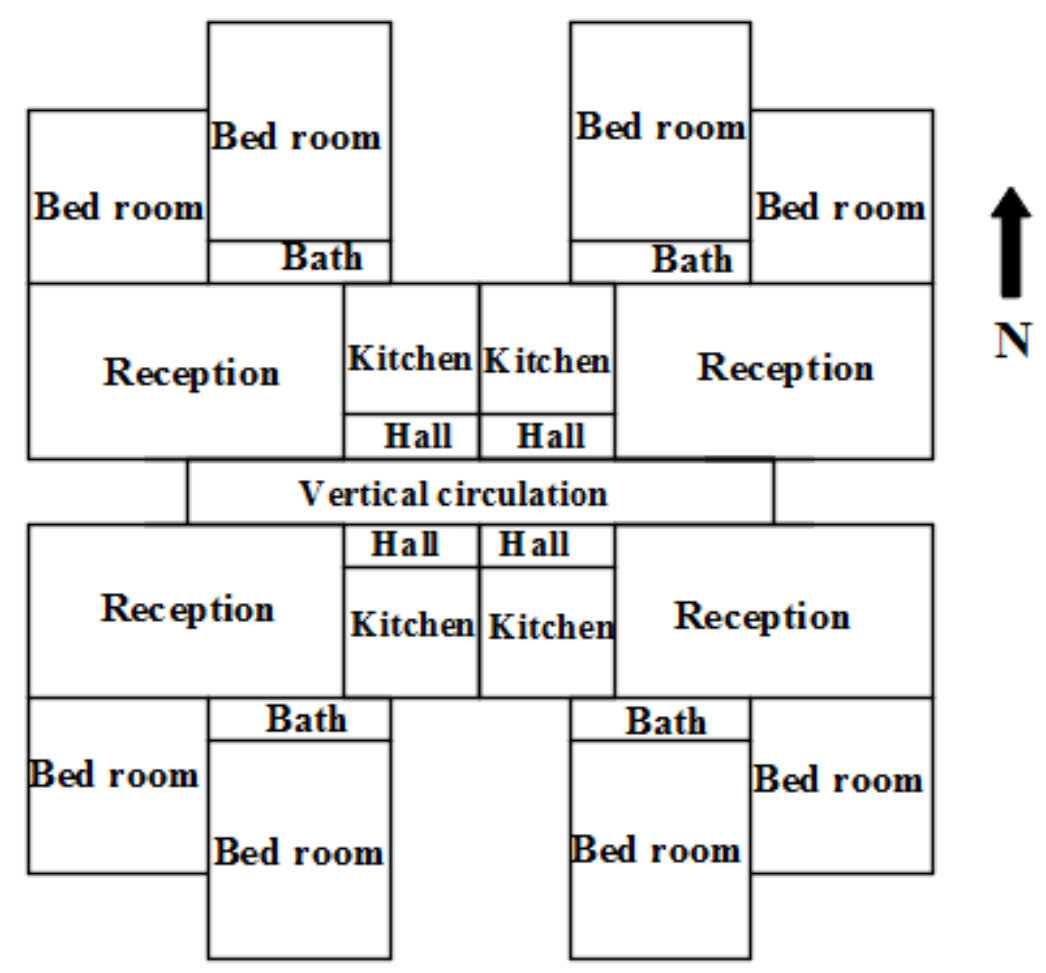

Fig.2 Plane space

The building components for this building are assumed to meet the requirements for Energy efficiency for residential building code [9].Characteristic of building components is given in Table 1 .

Table 1 Envelope performance characteristic [4]

\begin{tabular}{lc}
\hline Characteristics & Value \\
\hline overall heat transfer coefficient & $\mathrm{W} / \mathrm{m}^{2} . \mathrm{K}$ \\
\hline Exterior wall & 1.7 \\
Exterior roof & 0.319 \\
External glazing & 5.05 \\
\hline The maximum leakage rate factor & L/s per square meter of fenestration area \\
\hline Exterior wall & 1.7 \\
\hline The window to wall ratio(WWR) with no shading & \\
\hline Exterior wall & 0.3 \\
\hline
\end{tabular}


Table 2 gives the peak internal heat gain for each apartment space. Figure 3 shows the seasonally internal gain schedules for each apartment space [21]. The most set points were $21^{\circ} \mathrm{C}$ heating, $24^{\circ} \mathrm{C}$ cooling during occupied house. There is 2-hours the most worm-up period between 6 am and 8 am week day morning [9]. These internal gain schedules differ from space to another. Each space has its schedules of lighting, people and equipment loads as shown in Fig. 3. The people occupation of building defines the number of person and their activities. The Peak demands for some given months in the year and using this peak to make a fractional schedule for the hourly usage by dividing each consumption by the peak one and make a fractional percentage that could be used in domestic hot water (DHW) Schedules. It is found that hot water demand is $89 \mathrm{~L} /$ day in winter, while it is $54 \mathrm{~L} /$ day in summer [21].

Table 2 The peak internal gains [4]

\begin{tabular}{|c|c|c|c|c|c|}
\hline & Bed room-1 & Bed room-2 & Reception & Kitchen & Bath \\
\hline Lighting W/m $\mathrm{m}^{2}$ & 10 & 10 & 19 & 11 & 14 \\
\hline occupancy W/m ${ }^{2}$ & 7.4 & 12.8 & 18.3 & 21 & 26 \\
\hline Electrical equipment $\mathrm{W} / \mathrm{m}^{2}$ & 6 & 6 & 6 & 6 & 6 \\
\hline
\end{tabular}



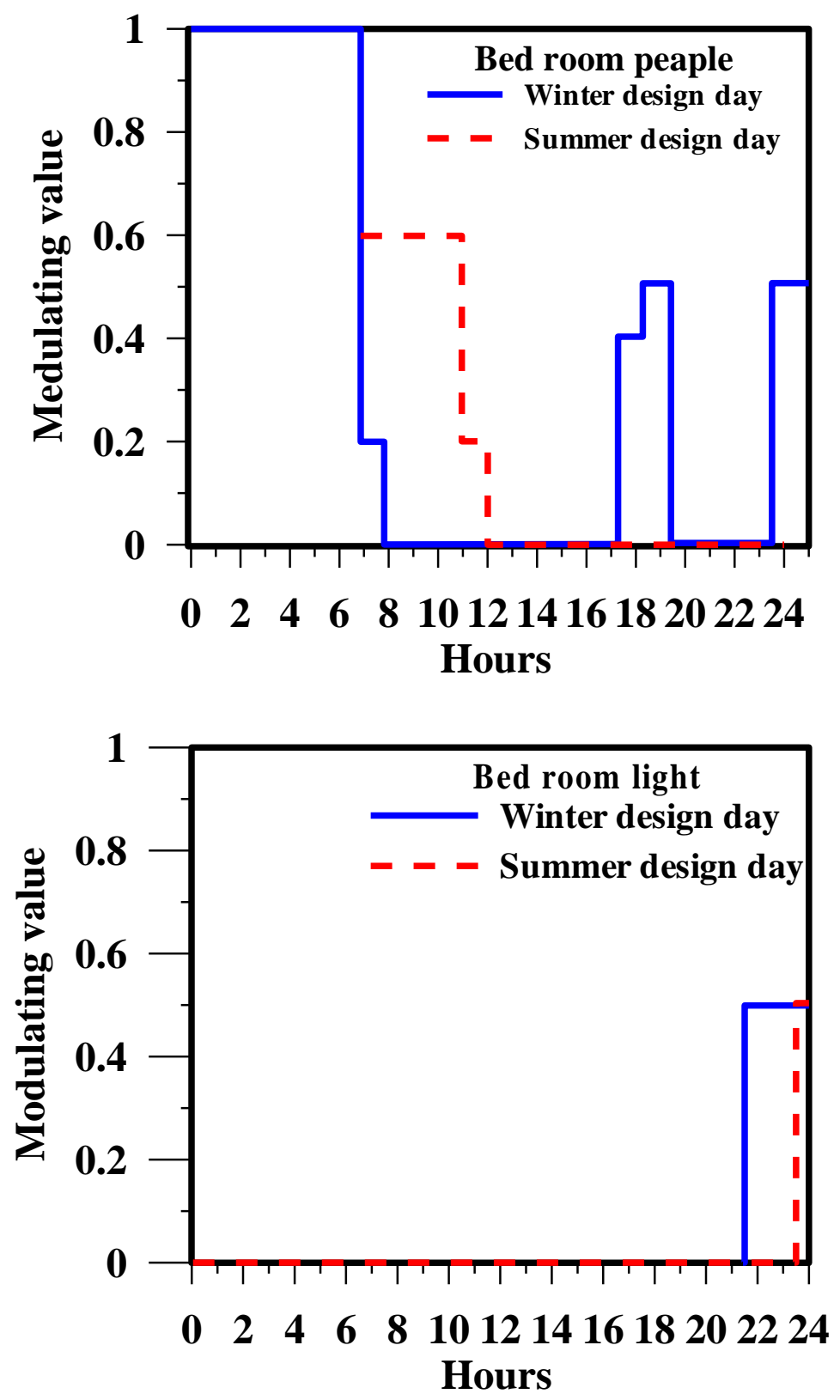

(a) Bed room schedules

Fig 3. 1 The hourly peak schedule [21] 

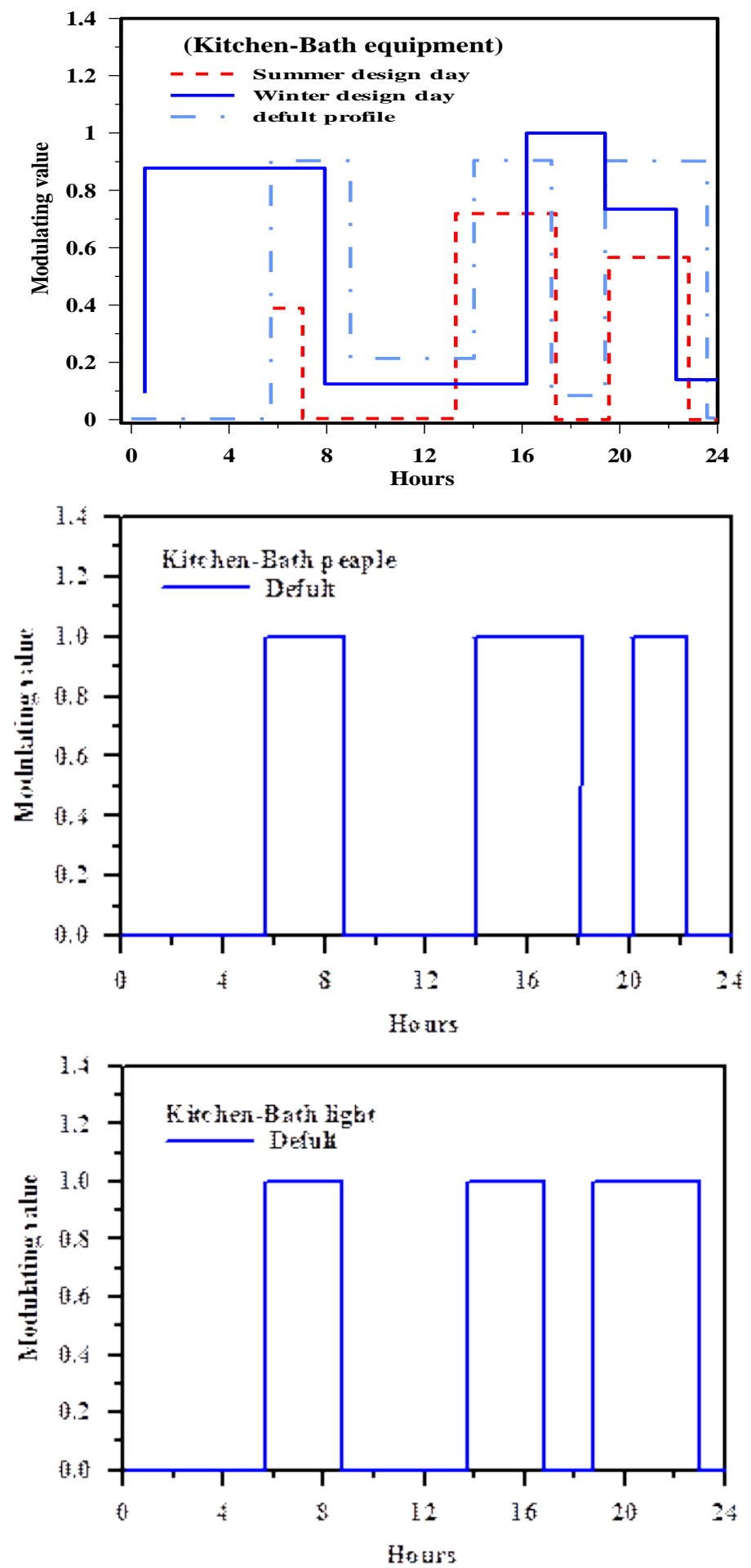

(b) Kitchen -bath schedules

Fig. 3. 2 The hourly peak schedule [21] 

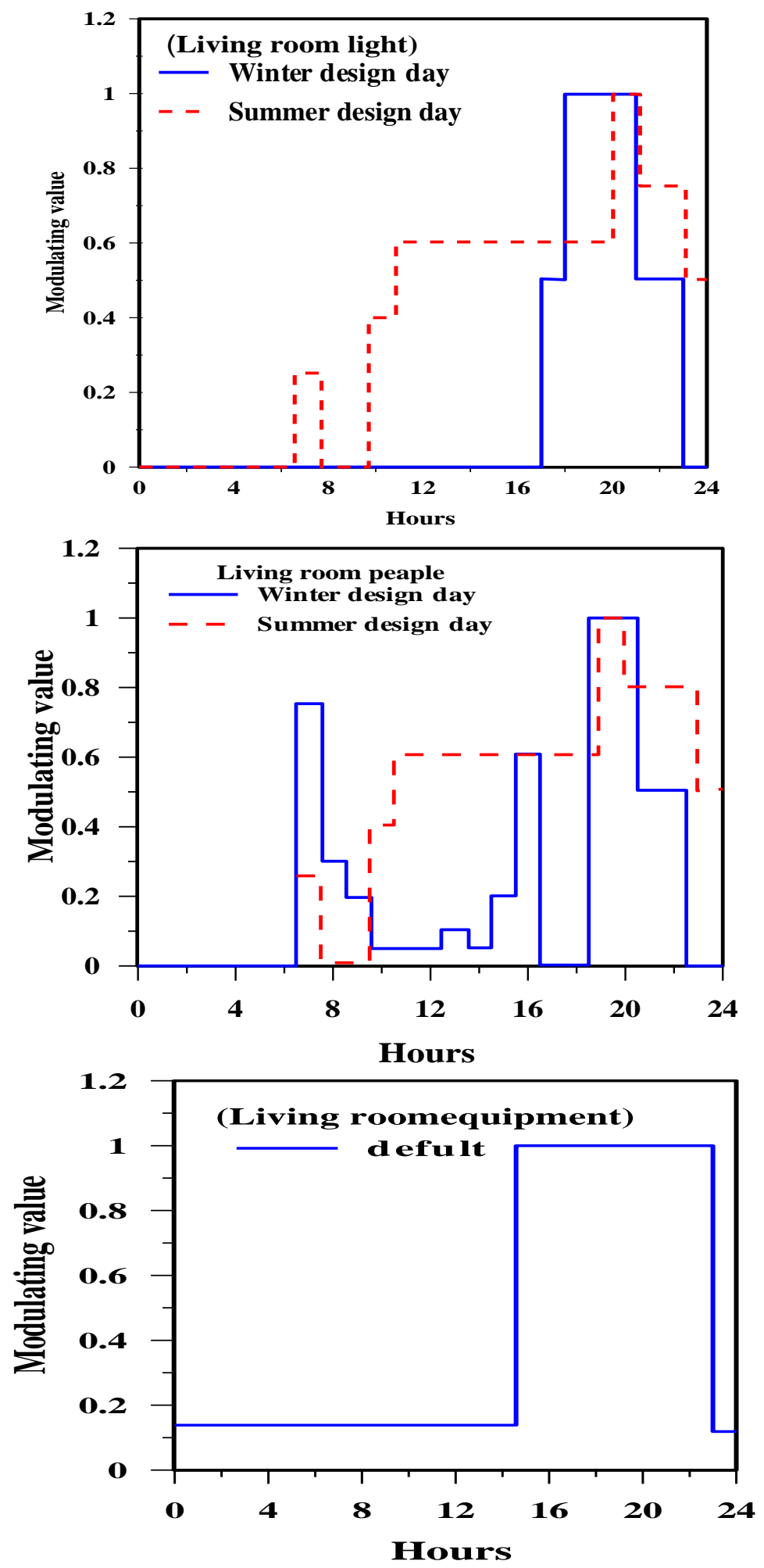

(c) Living room schedules

Fig 3. 3 The hourly peak schedule [21] 


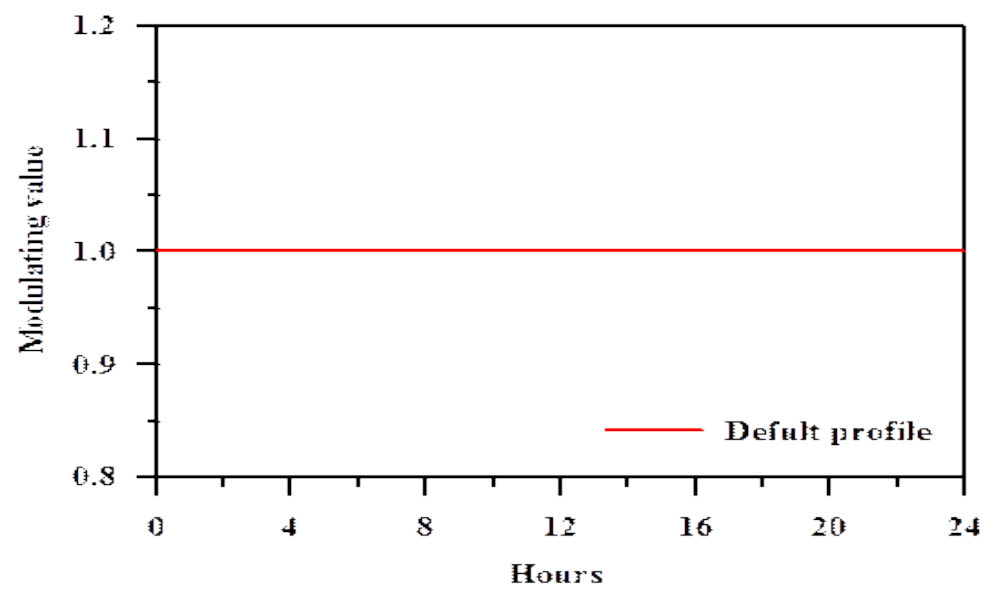

(d)Hall (corridor) schedules
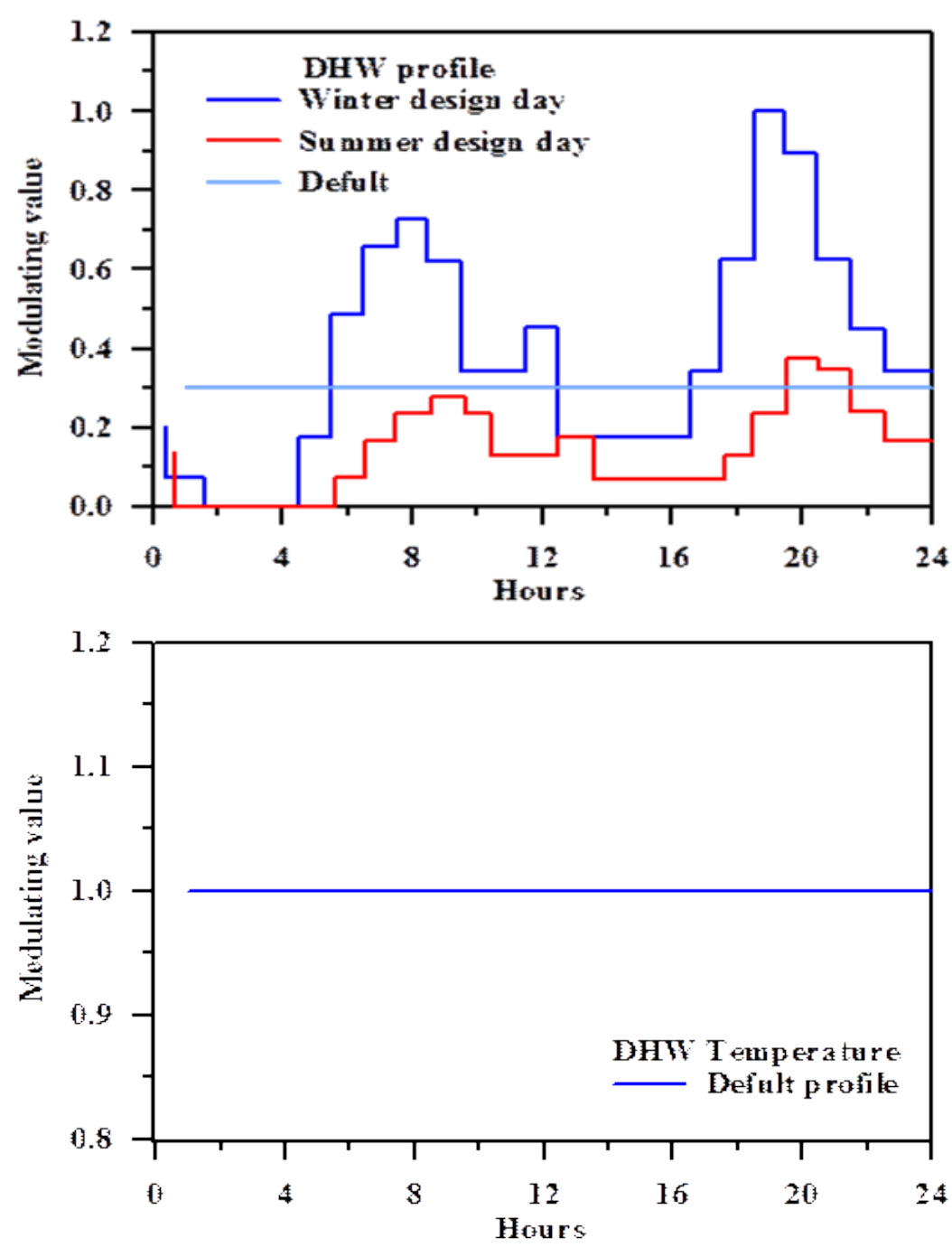

(e)DHW schedules

Fig 3. 4The hourly peak schedule [21] 


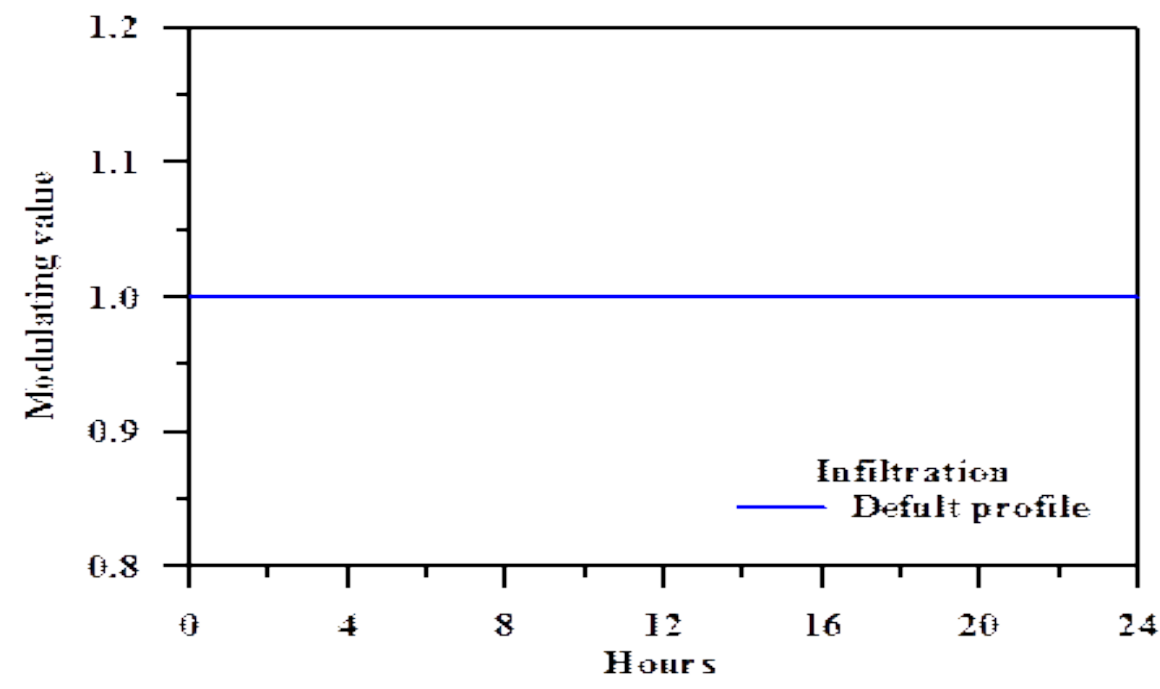

(f)Infiltration schedules

Fig.3.5 The hourly peak schedule [21]

\subsubsection{EEMs description}

There are many parameters are affecting the total heating and cooling energy consumption in buildings such as external shading, adding thermal insulation for exterior walls and roofs, etc. This section aims to predict the effect of implemented EEMs on the building demand whether cooling, heating and electrical demands. The implemented EEMs are adding external shading, adding thermal insulation for exterior walls, changing of the window glazing type and changing the type of fixture lighting. The first implemented EEM is adding external shading with different projection factors (from 0.1 to 0.9 ). The projection factor (P.F) is defined as the ratio between the horizontal distance of shading to the window height when the shading is installed to adjustment to the window top edge [11]. It may be noted that the shading is added to all windows of either each exterior wall orientation (North, south, east, west) or all exterior wall orientations.

The second implemented EEM is adding thermal insulation within the exterior wall. The insulation material, which has thermal conductivity $0.04 \mathrm{~W} / \mathrm{m} \mathrm{K}$, density 16 $\mathrm{kg} / \mathrm{m}^{3}$, specific heat $840 \mathrm{~J} / \mathrm{kg} \mathrm{K}$, is added. The insulation thickness is changed from 
$0.01 \mathrm{~m}$ to $0.045 \mathrm{~m}$ with step $0.005 \mathrm{~m}$. The overall thermal resistance of the exterior wall is changed from $0.84 \mathrm{~m}^{2} . \mathrm{K} / \mathrm{W}$ to $1.7 \mathrm{~m}^{2} . \mathrm{K} / \mathrm{W}$. The third implemented EEM is the window glazing type as shown in Table 3.

The fourth implemented EEM is changing lighting fixture to be based on compact fluorescent lamp (CFL) and light emitting diode (LED) having high lighting efficiency. (i.e. low electrical wattage and high lighting lumens). Table 4 summarizes the wattage intensity in all spaces taking into consideration that the same lighting intensity must be achieved. Finally, it can be a make combination from all EEMs to reach the lowest energy needs.

Table 3 Glass types characteristics [4]

\begin{tabular}{l|c|cc}
\hline Name & $\begin{array}{c}\text { Over all heat transfer } \\
\text { coefficient, } \\
\left(\mathrm{W} / \mathrm{m}^{2} \mathrm{~K}\right)\end{array}$ & $\begin{array}{c}\text { Solar heat gain } \\
\text { coefficient } \\
\text { SHGC }\end{array}$ & $\begin{array}{c}\text { The visible } \\
\text { lighting } \\
\text { transmittance } \\
\text { TVIS }\end{array}$ \\
\hline Single glazing clear & 6.17 & 0.81 & 0.88 \\
\hline $\begin{array}{l}\text { Single reflective }(\mathrm{A}) \text { tint } \\
\text { medium emissivity }\end{array}$ & 5.11 & 0.25 & 0.09 \\
\hline $\begin{array}{l}\text { Double Glazing tint low } \\
\text { emissivity }\end{array}$ & 1.78 & 0.28 & 0.44 \\
\hline
\end{tabular}

Table 4 Different wattage intensity $\left(\mathrm{W} / \mathrm{m}^{2}\right)[4]$

\begin{tabular}{lccc}
\hline \multirow{2}{*}{ Space } & \multicolumn{3}{c}{ Light type } \\
\cline { 2 - 4 } & Base case[Watt $\left./ \mathrm{m}^{2}\right]$ & CFL $\left[\right.$ Watt $\left./ \mathrm{m}^{2}\right]$ & LED $\left[\mathrm{Watt} / \mathrm{m}^{2}\right]$ \\
\hline Bedroom & 14 & 1.28 & 1.07 \\
\hline Guest room & 19 & 5.14 & 4.28 \\
\hline Living room & 14 & 5.14 & 4.28 \\
\hline Bathroom & 10 & 2.57 & 2.14 \\
\hline Kitchens & 11 & 3.43 & 2.86 \\
\hline Corridors & 14 & 2.57 & 2.14 \\
\hline
\end{tabular}


Direct expanding split (DX) air conditioning unit without inverter is installed in the residential buildings. It is assumed to be used in the air conditioning spaces in the base model to calculate the delivered electricity. The coefficient of performance values of air-conditioning unit operating in cooling and heating modes are 3 and 4, respectively, in compliance with the Energy efficiency for residential building code [9].

Initially, the base case model of the residential building is defined and simulated to obtain its performance characteristics. The building simulation is carried out using combination of software tools. Sketch-up 2017 version Windows 64-bit 17.2.2555 is used to draw the building model. The basic characteristic of the building model envelope, internal gains, schedules ...etc. are defined using Open-Studio version 2.3.0. Finally, Energy Plus version V8-6-0 0 is used as a building simulation tool to get the simulation results. These three combined tools were used by several researches in literature $[11,16,17]$.

\subsection{Results and discussion}

This section presents the energy demands in the base and modified cases of the low-income high rise residential building. The results are categorized into thermal and electrical demands. The thermal demands include space cooling and space heating, while the electrical demand includes lighting, equipment, domestic hot water heater, pump and fans.

Fig .4 indicates the annual space cooling of the base case of the low-income high rise residential building under Cairo climatic conditions. It is found that the space cooling demand increases to $50 \mathrm{~W} / \mathrm{m}^{2}$ at 4000 hour then decreases. The hourly annual space heating demands is presented in Fig.5 Clearly, it increases to $32.5 \mathrm{~W} / \mathrm{m}^{2}$ at 2000hours (winter season) then decreases to $0 \mathrm{~W} / \mathrm{m}^{2}$ from 2000hours to 7500 (summer season) after that increases to $21 \mathrm{~W} / \mathrm{m}^{2}$ from 7500 hours to the end of the year (summer season). The peak of the thermal cooling and heating demands are $50 \mathrm{~kW}$ and $32.5 \mathrm{~kW}$, respectively, as shown in Fig. 6. 


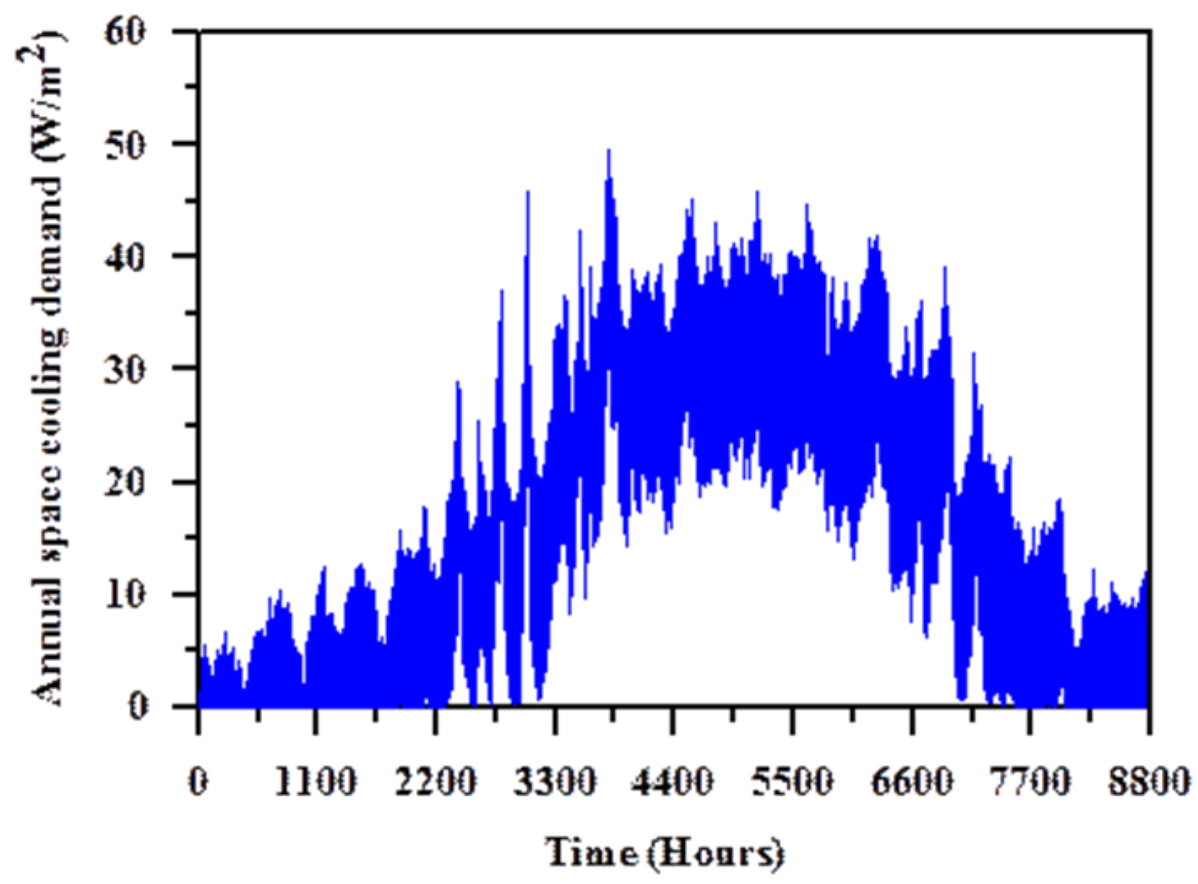

Fig .4 Base case normalized annual space cooling demand

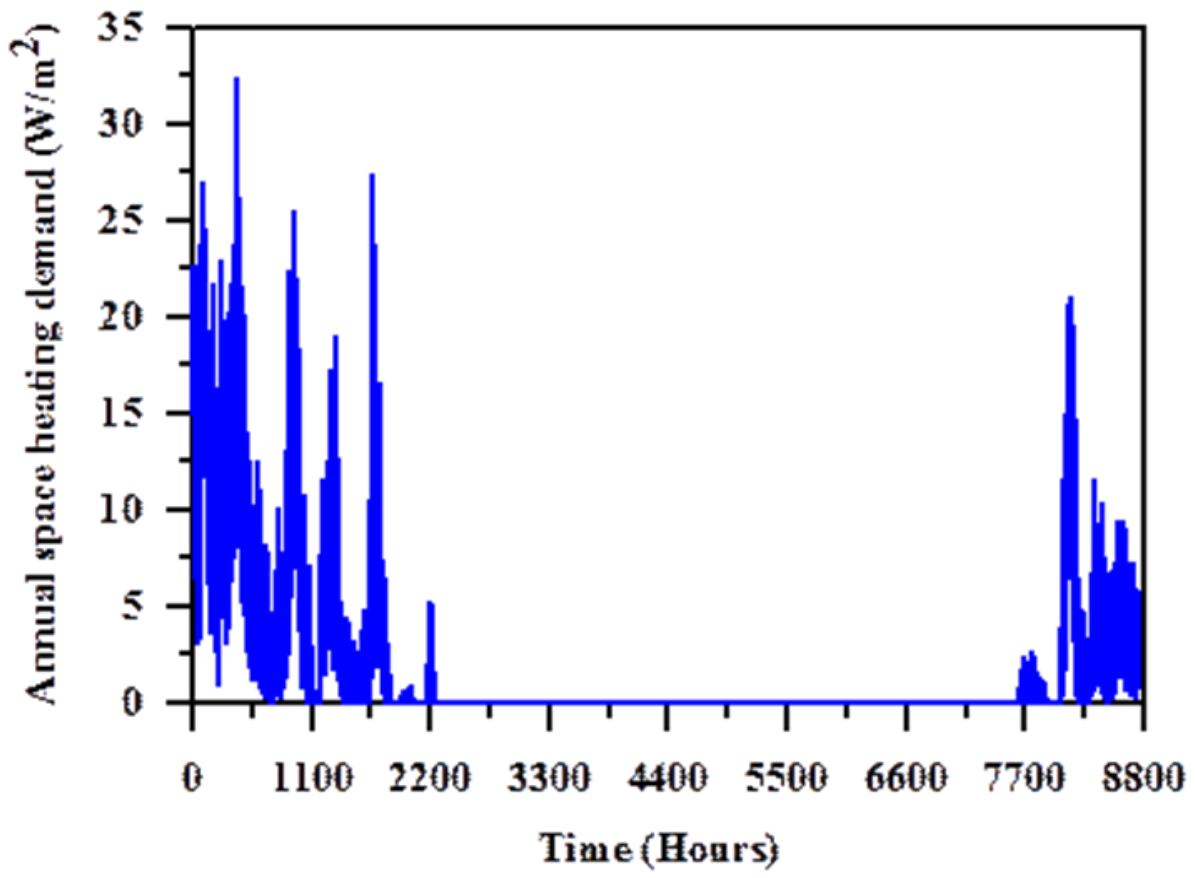

Fig 5 Base case normalized space heating demand 


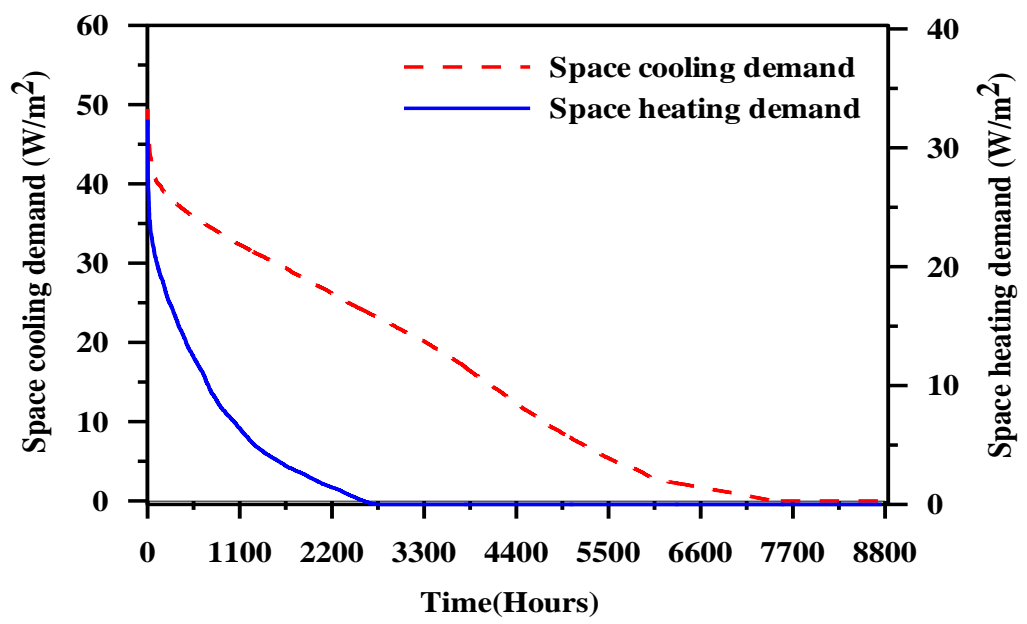

Fig.6 Duration time base case normalized space cooling and heating demand

Fig.7 shows monthly breakdown energy demands. It can be noticed that the space cooling demand reaches the peak monthly value of $18.5 \mathrm{kWh} / \mathrm{m}^{2}$ in July. The space heating demand reaches the peak monthly value of $1.8 \mathrm{kWh} / \mathrm{m}^{2}$ in January, while the hot water demand reaches its peak value of $4 \mathrm{kWh} / \mathrm{m}^{2}$ per month in winter months. Fig. 8 reveals that the cooling and heating demand electricity are $130 \mathrm{kWh} / \mathrm{m}^{2} \mathrm{a}$ and 6.5 $\mathrm{kWh} / \mathrm{m}^{2}$.a, respectively. Fig. 9 indicates that the cooling and heating delivered electricity are $56 \mathrm{kWh} / \mathrm{m}^{2}$.a and $5.7 \mathrm{kWh} / \mathrm{m}^{2}$.a corresponding to $35 \%$ and $4 \%$ of the total annual delivered electricity, respectively. Fig.10 shows Average ambient Temperature used in this research and last 5 years of Cairo. In our case, the objective to study the annual performance demands of residential building in compliance with Energy Efficiency Residential Building Code, ECP-306 [4]. To validate our results, there was not enough published works that had quite similar or sufficient model inputs such as the investigated building typology, weather file used, load and occupancy schedule that can be compared with our case. However, in Attia [22] based on the electrical demand survey done depending on the utility bill for residential apartment (more than 500) in Cairo, it is noticed that the annual electrical demand varies from 90 to $18 \mathrm{kWh} / \mathrm{m}^{2}$.a depending on the life style, appliances, DWH heater (gas heater or electrical one), and number of $\mathrm{A} / \mathrm{C}$ per apartment. Our results indicated that the total 
electrical demand of cooling, heating, appliances, and lighting is $107.2 \mathrm{kWh} / \mathrm{m}^{2}$.a. The variation mostly is depending on differences of the building typology, load schedule, and in our case, we consider $\mathrm{A} / \mathrm{C}$ is installed in bedrooms and living room. Other studied also presented the annual electrical demand is $110 \mathrm{kWh} / \mathrm{m}^{2}$.a [23] and 45 $\mathrm{kWh} / \mathrm{m}^{2} . \mathrm{a}$ [24] for residential building in Cairo. Based on this clarification, it can be concluded that the results of this work are reasonable.

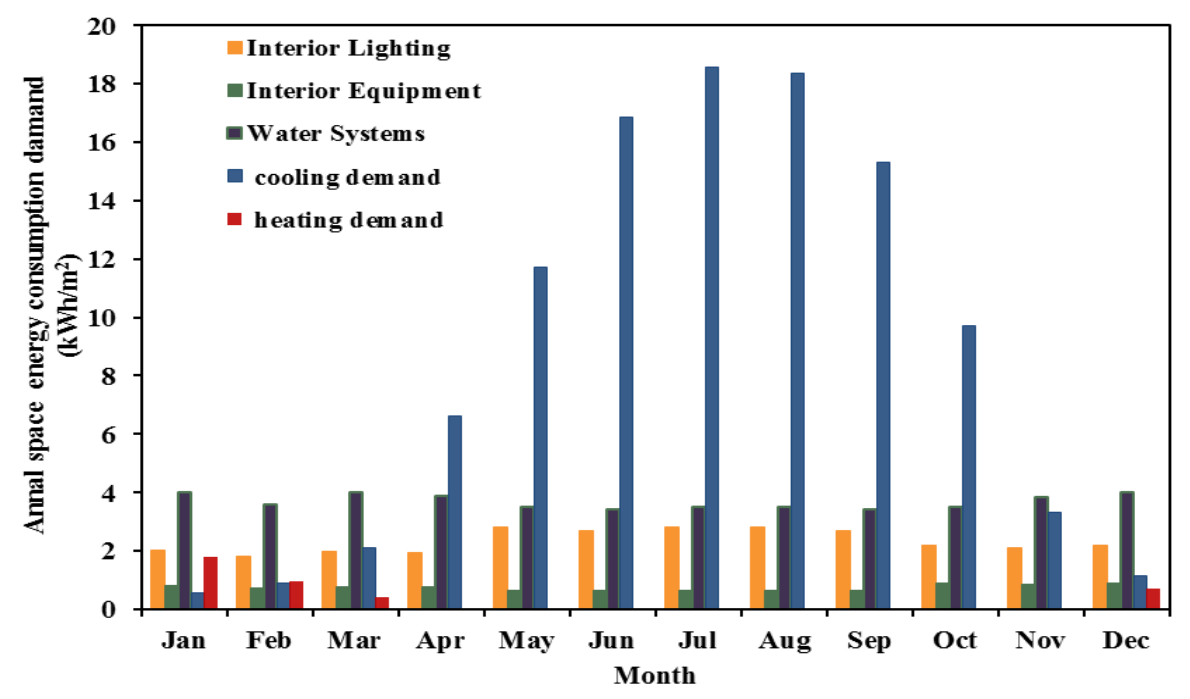

Fig. 7 Base case monthly space energy consumption $\left(\mathrm{kWh} / \mathrm{m}^{2}\right.$ per month)

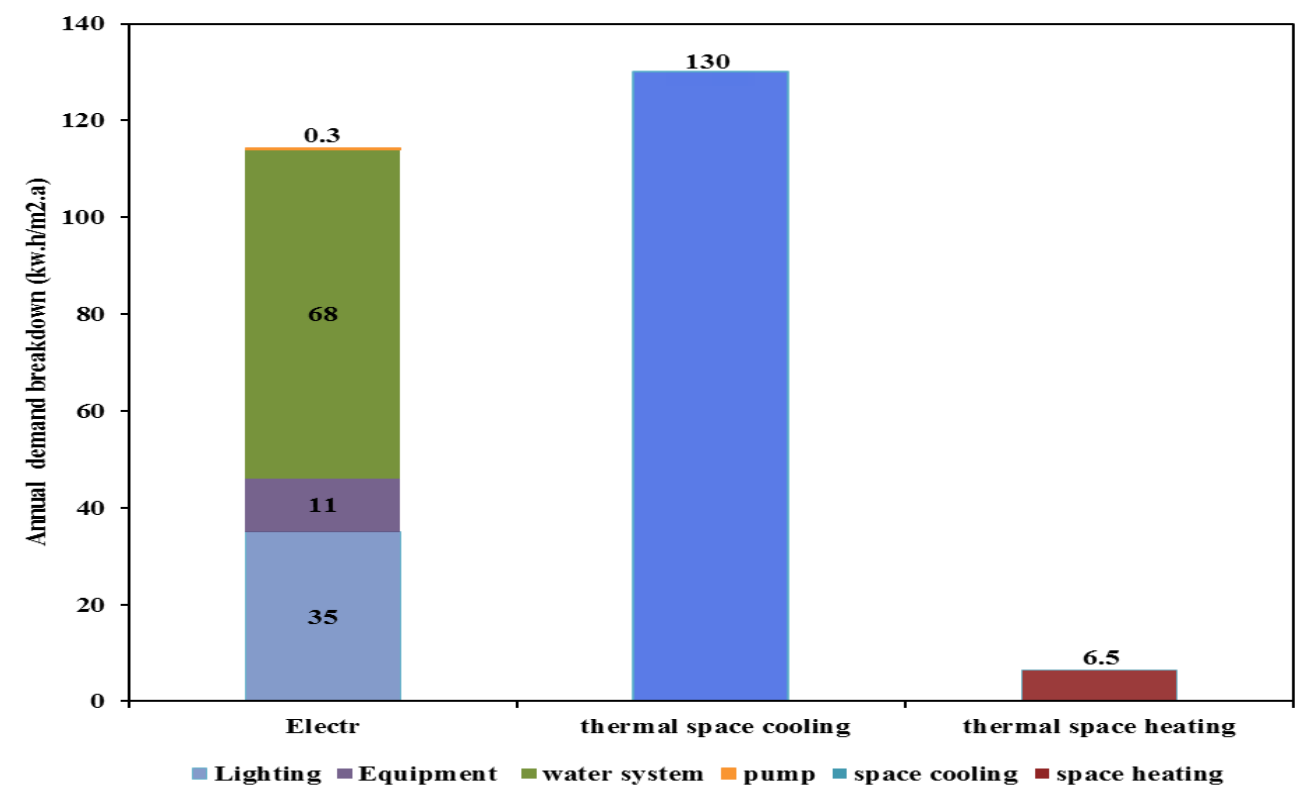

Fig. 8 Base case annual demand breakdown. 


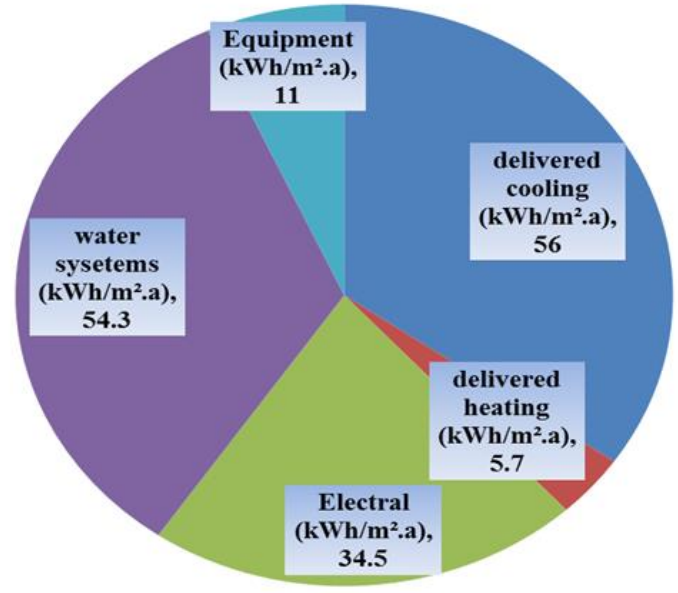

Fig. 9 Electrical delivered energy $\left(\mathrm{kWh} / \mathrm{m}^{2}\right.$.a)

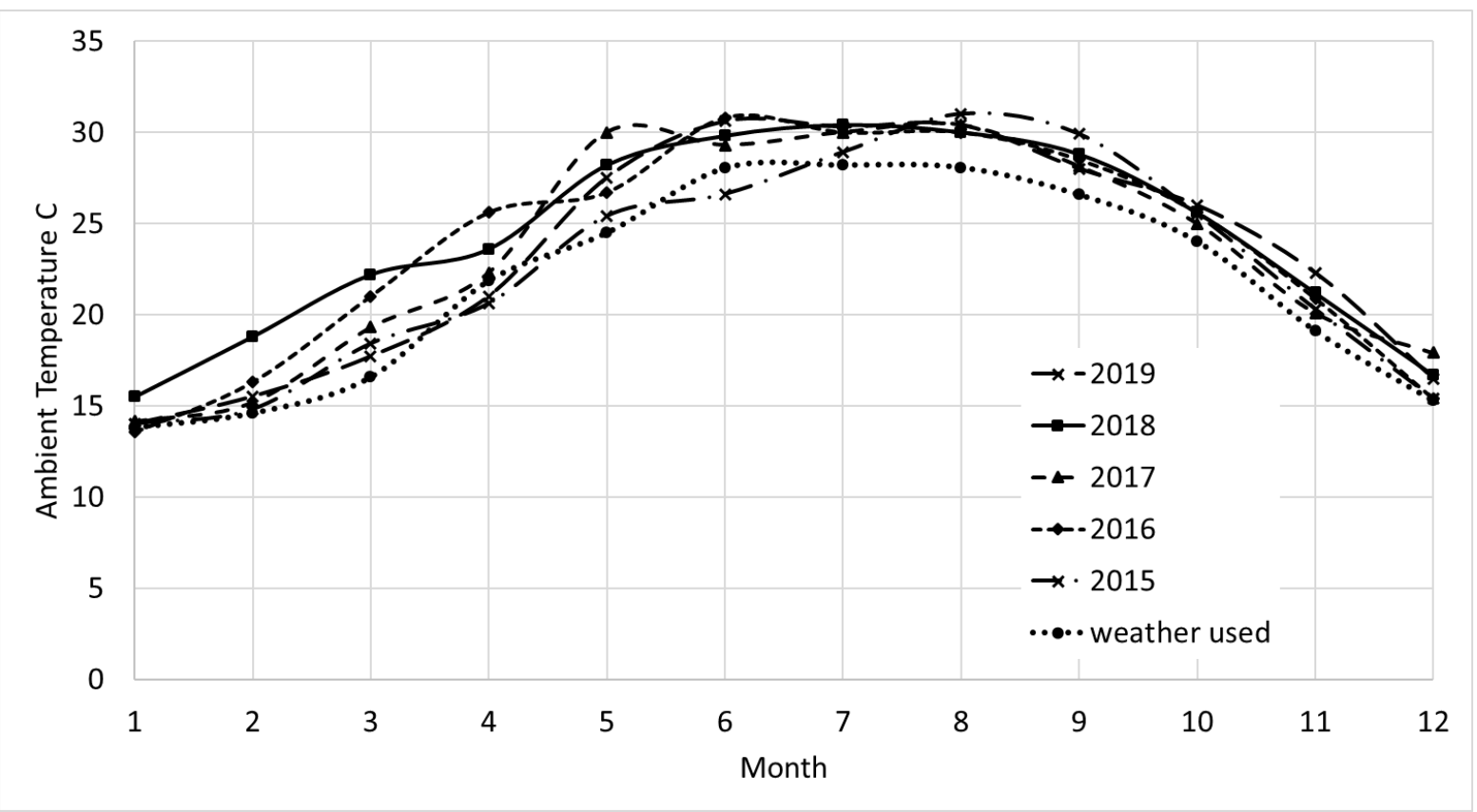

Fig. 10 Average ambient Temperature used in this research and last 5 years of Cairo [25]

\subsubsection{Effect of external shading}

Fig.11 illustrates the effect of shading projection factor (PF) on the annual space cooling demand. The results show that the PF has larger energy saving on the annual cooling demand when it is installed on the east and west façade where larger exterior glazing is existing. PF of 0.9 decreases the annual cooling demand by $5 \%$, if it is used 
whether on east or west façade while the energy saving increases to $13 \%$ by installing the exterior shading on all building façade.

Effect of shading projection factor on annual space heating demands is shown in Fig. 12, which confirms PF has larger energy saving on the annual heating demand when it is installed on the south, east façade where larger exterior glazing is exist. Clearly, PF of 0.9 increase the annual heating demand by $9 \%$ or $8 \%$ when it is used whether on south or east façade while the annual heating saving increases by $31 \%$ if the exterior shading is installed on all building façade

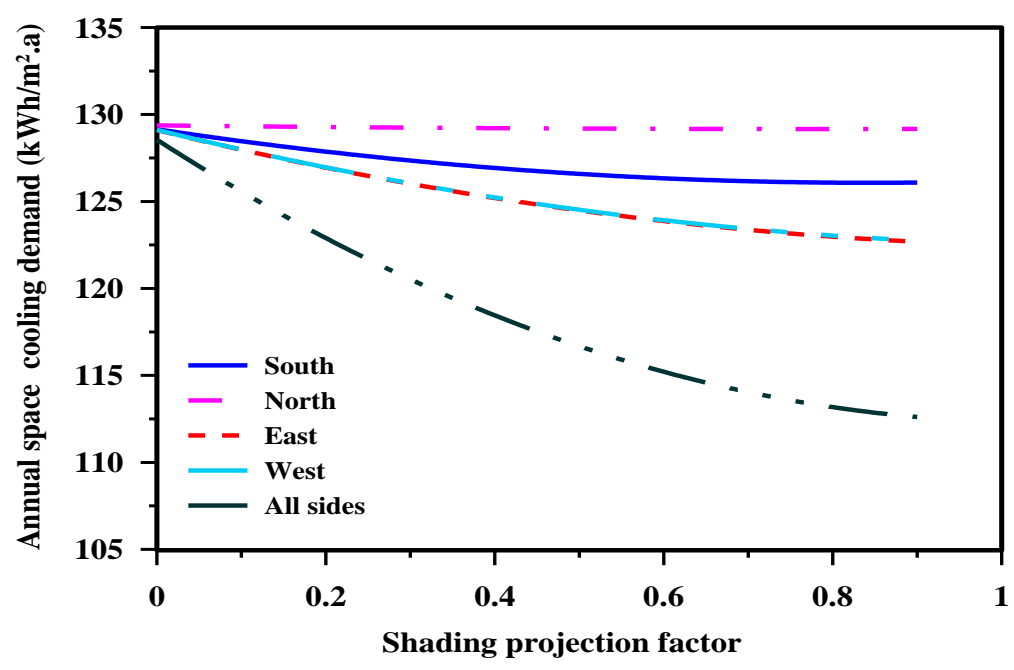

Fig. 11 Effect of shading projection factor on annual space cooling demand

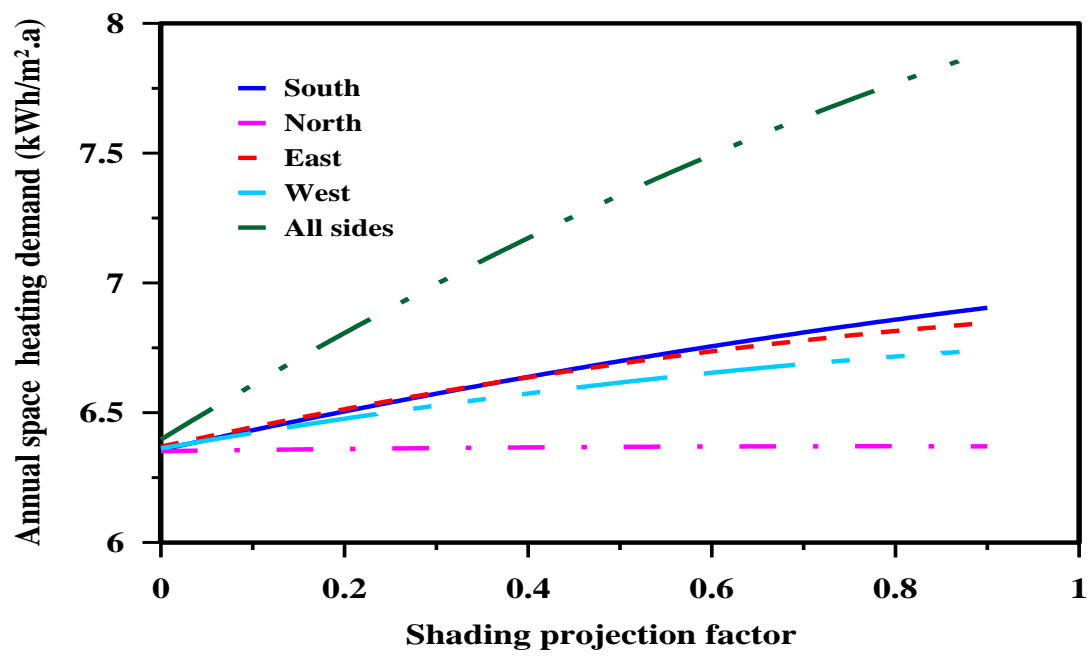

Fig. 12 Effect of shading projection factor on annual space heating demand 
Table 5 shows the effect of increasing shading projection factor on the heating and cooling electrical delivered needs by air-conditioning system. Clearly, the external shading with PF of 0.9 maximum effects on all sides direction. The delivered heating increase with $0.9 \mathrm{kWh} / \mathrm{m}^{2}$.a (16\%) due to increase in PF from 0 to 0.9 . The delivered cooling decrease with $6 \mathrm{kWh} / \mathrm{m}^{2}$.a $(11 \%)$. The results show the external shading decreases the total electricity with $7.5 \mathrm{kWh} / \mathrm{m}^{2}$.a.

Table 5 Effect of shading projection factor on annual space cooling, heating and total electrical delivered $\left(\mathrm{kWh} / \mathrm{m}^{2} . \mathrm{a}\right)$

\begin{tabular}{cccc}
\hline $\begin{array}{c}\text { shading } \\
\text { projection factor }\end{array}$ & $\begin{array}{c}\text { Delivered space cooling } \\
{\left[\mathbf{k W h} / \mathbf{m}^{\mathbf{2}} \mathbf{. a}\right]}\end{array}$ & $\begin{array}{c}\text { Delivered space } \\
\text { heating }\left[\mathbf{k W h} / \mathbf{m}^{\mathbf{2}} \mathbf{. a}\right]\end{array}$ & $\begin{array}{c}\text { Total electricity } \\
\text { delivered }\left[\mathbf{k W h} / \mathbf{m}^{\mathbf{2}} \mathbf{. a}\right]\end{array}$ \\
\hline 0.0 & 56 & 5.7 & 189 \\
\hline 0.1 & 54 & 6 & 187 \\
\hline 0.3 & 53 & 6.2 & 185 \\
\hline 0.5 & 52 & 6.3 & 184 \\
\hline 0.6 & 51 & 6.4 & 183 \\
\hline 0.7 & 51 & 6.5 & 182.5 \\
\hline 0.9 & 50 & 6.6 & 181.5 \\
\hline
\end{tabular}

\subsubsection{Effect of exterior wall insulation}

Fig.13 indicates the effect of exterior wall insulation thickness on annual thermal space cooling and heating demands. As the exterior wall insulation thickness increases, the annual thermal space cooling decreases by $7 \%$ of the total cooling demand, while the annual thermal space heating demand decreased by $60 \%$ of the total heating demand of the base case. These percentages represent $9 \mathrm{kWh} / \mathrm{m}^{2}$.a and $3.85 \mathrm{kWh} / \mathrm{m}^{2} . \mathrm{a}$. The reason is reducing the overall heat transfer coefficient of external wall reduces the external heat gain from outside in winter and heat loss from inside to outside in summer. That decreases the cooling demand and heating demand. 
Table 6 illustrates the effect of exterior wall insulation thickness on cooling and heating electrical energy of air- conditioning unit. Clearly, the exterior wall with thermal resistance of $1.7 \mathrm{~m}^{2} \mathrm{~K} / \mathrm{W}$ implemented on all sides with insulation thickness of 0.045 has maximum energy saving. The delivered heating decreases with 1.9 $\mathrm{kWh} / \mathrm{m}^{2} \cdot \mathrm{a}(33 \%)$. The delivered cooling decrease with $4.7 \mathrm{kWh} / \mathrm{m}^{2} . \mathrm{a}(8 \%)$. The results show the increasing of exterior wall insulation thickness decreases the total electricity with $8.5 \mathrm{kWh} / \mathrm{m}^{2} . \mathrm{a}(4.5 \%)$.

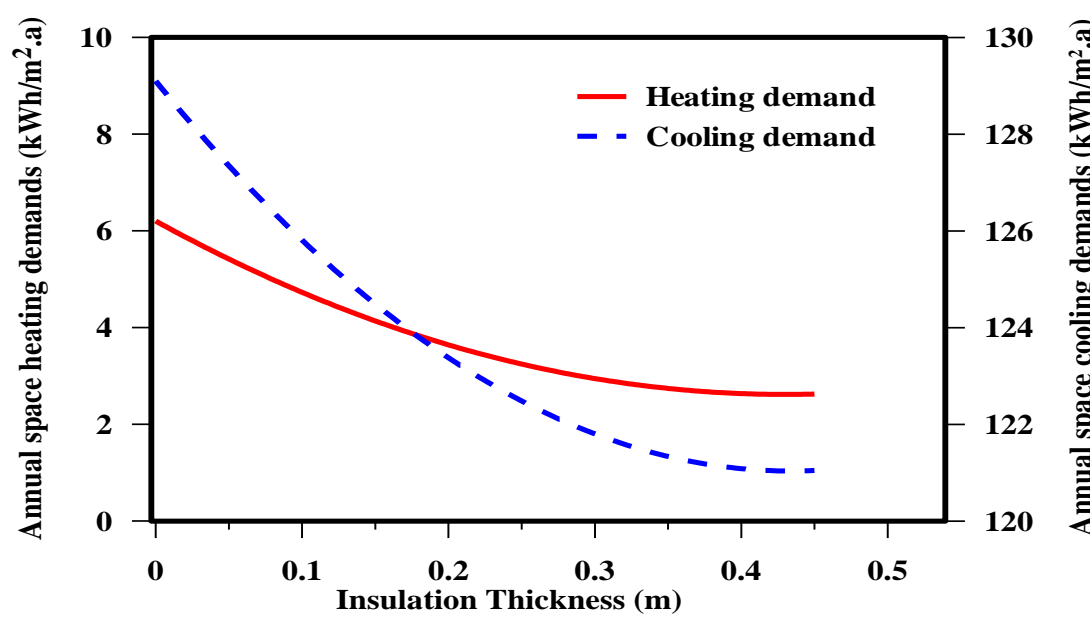

Fig. 13 Effect of wall insulation thickness on annual space cooling and heating demands

Table 6 Effect of shading projection factor on annual space cooling, heating delivered and total electricity consumption $\left(\mathrm{kWh} / \mathrm{m}^{2} . \mathrm{a}\right)$

\begin{tabular}{|c|c|c|c|}
\hline $\begin{array}{l}\text { exterior wall insulation } \\
\text { thickness }[\mathrm{m}]\end{array}$ & $\begin{array}{c}\text { Delivered space } \\
\text { cooling[kWh/m².a] }\end{array}$ & $\begin{array}{c}\text { Delivered space } \\
\text { heating }\left[\mathrm{kWh} / \mathrm{m}^{2} . \mathrm{a}\right]\end{array}$ & $\begin{array}{c}\text { Total electricity } \\
\text { consumption }\left[\mathrm{kWh} / \mathrm{m}^{2} . \mathrm{a}\right]\end{array}$ \\
\hline 0 & 56 & 5.7 & 187 \\
\hline 0.01 & 54 & 5 & 184 \\
\hline 0.015 & 53.4 & 4.7 & 183 \\
\hline 0.02 & 53 & 4.5 & 182 \\
\hline 0.025 & 52.4 & 4.3 & 181 \\
\hline 0.03 & 52 & 4.1 & 180 \\
\hline 0.035 & 51.7 & 4 & 179.5 \\
\hline 0.04 & 51.5 & 3.9 & 179 \\
\hline 0.045 & 51.3 & 3.8 & 178.5 \\
\hline
\end{tabular}




\subsubsection{Effect of window glazing type}

Fig.14 shows the effect of window glazing type on the total heating and cooling demands. The maximum energy saving of the annual space cooling demand is about $14 \%$, as it decreases from $130 \mathrm{kWh} / \mathrm{m}^{2}$.a in base case to $111.5 \mathrm{kWh} / \mathrm{m}^{2}$.a when using double glazing type. The maximum energy saving in the annual space heating demand is nearly $31 \%$, when the double glazing type is used. It decreases from $6.5 \mathrm{kWh} / \mathrm{m}^{2}$.a to $4.5 \mathrm{kWh} / \mathrm{m}^{2} . \mathrm{a}$.

\subsubsection{Effect of the type of fixture lighting}

Fig.15 illustrates the effect of fixture lighting type on the annual space cooling and heating demand. Clearly, the best energy consumption when using LED lighting implementing CFL and LED lighting decreases the annual space cooling demand decreases with $22 \mathrm{kWh} / \mathrm{m}^{2} . \mathrm{a}(17 \%)$ and $23 \mathrm{kWh} / \mathrm{m}^{2} . \mathrm{a}(17 \%)$, respectively. The annual space heating demand increases with $1.5 \mathrm{kWh} / \mathrm{m}^{2}$.a (23\%) and $1.7 \mathrm{kWh} / \mathrm{m}^{2} . \mathrm{a}(26 \%)$, respectively. Fig.16 presents the effect of lighting type on the building. It is clear that the electricity consumption decreases by $25.5 \mathrm{kWh} / \mathrm{m}^{2}$.a $(25.5 \%)$, when using CFL lighting and decreases with $27 \mathrm{kWh} / \mathrm{m}^{2} . \mathrm{a}(27 \%)$ when using LED lighting to reach its minimum value with LED lighting $73 \mathrm{kWh} / \mathrm{m}^{2}$.a.

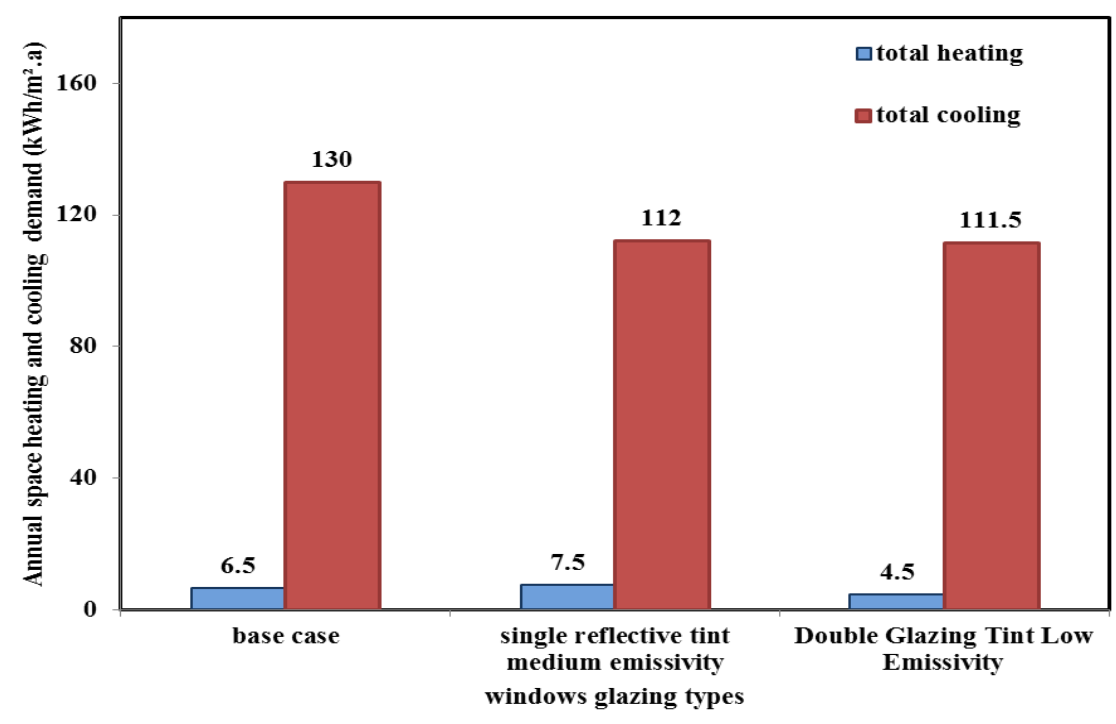

Fig. 14 Effect of window glazing type on annual space heating and cooling demand 


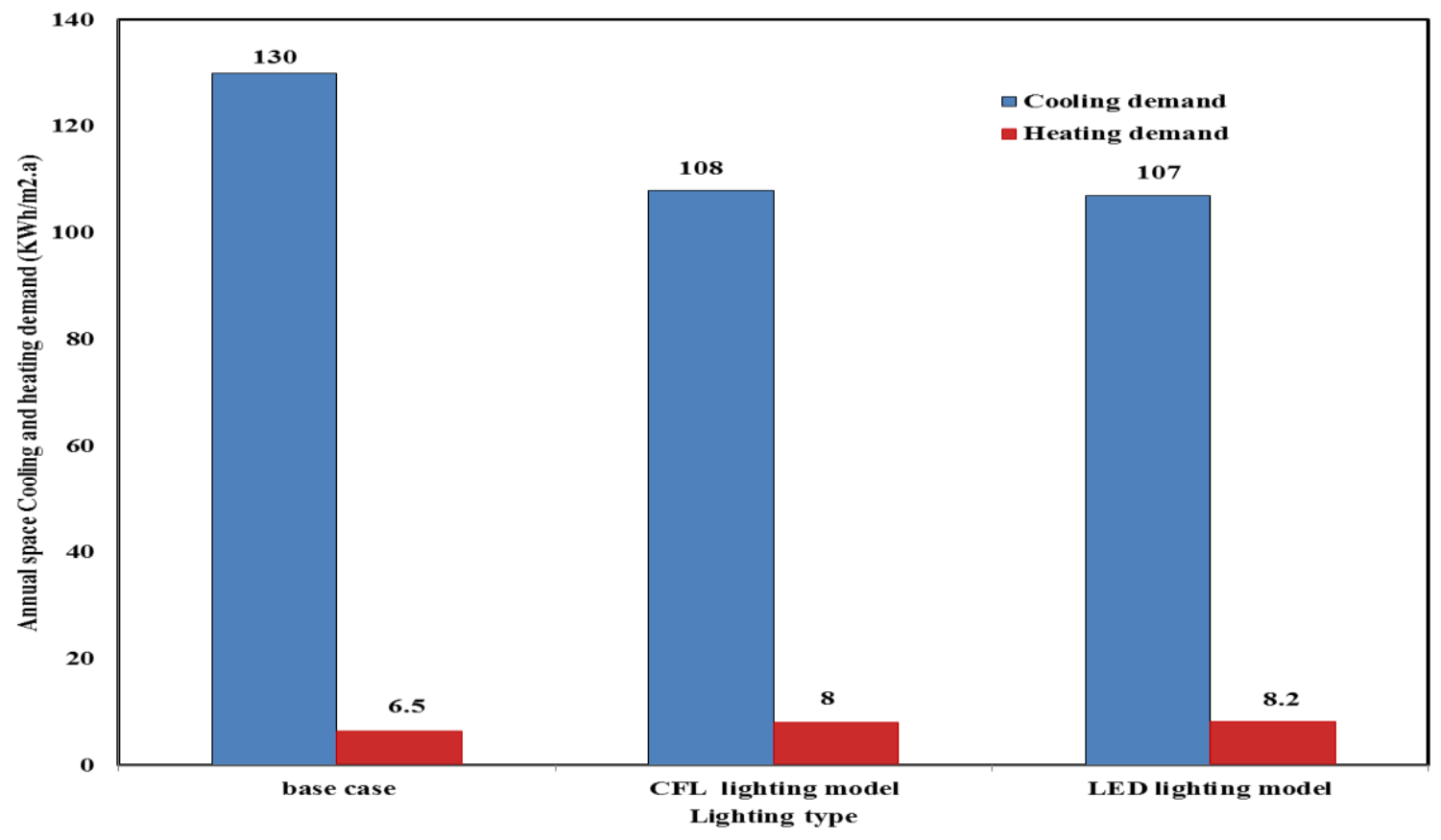

Fig. 15Effect of lighting type on annual space cooling and heating demands

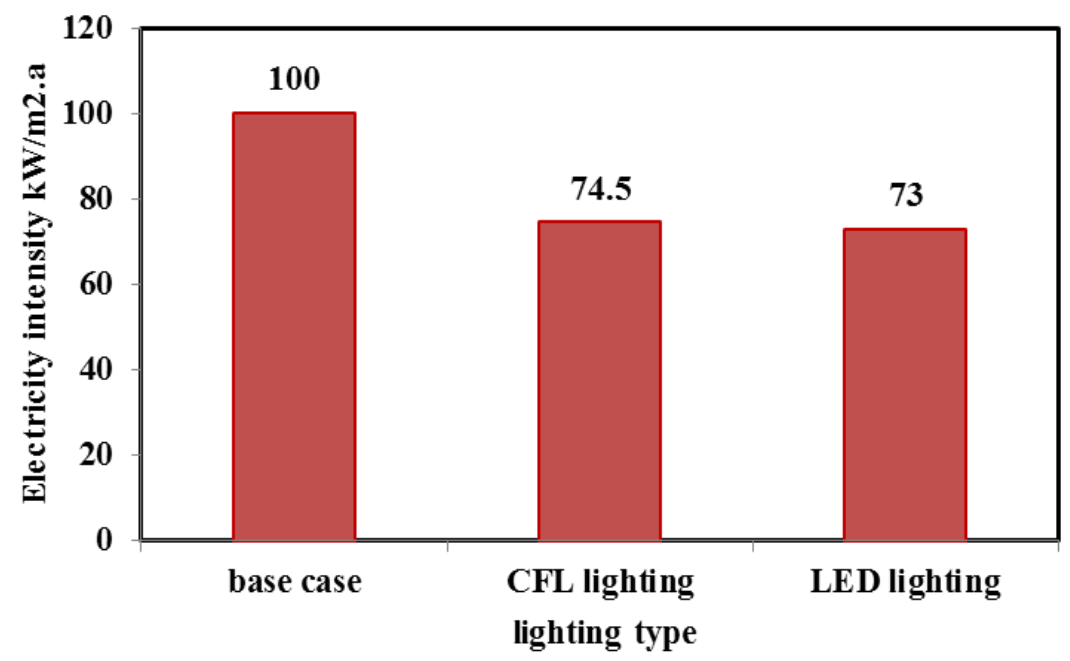

Fig. 16 Effect of lighting type on electricity intensity

Effect of lighting type on building with air conditioning system is shown in Fig.17, which reveals that the electricity consumption decreases by $32.5 \mathrm{kWh} / \mathrm{m}^{2} . \mathrm{a}$ (17\%) when using CFL lighting and decreases with $34 \mathrm{kWh} / \mathrm{m}^{2}$.a (18\%) when using LED lighting to reach its minimum value with LED lighting of $153 \mathrm{kWh} / \mathrm{m}^{2}$.a. Fig. 18 illustrates the influence of lighting type on the building with air conditioning system on 
the delivered cooling and heating. It is found that when using CFL and LED lighting, delivered cooling decreases with $6.8 \mathrm{kWh} / \mathrm{m}^{2} . \mathrm{a}(12 \%)$ and $7 \mathrm{kWh} / \mathrm{m}^{2} \cdot \mathrm{a}(12.5 \%)$, respectively. The delivered heating increases with $1.3 \mathrm{kWh} / \mathrm{m}^{2} . \mathrm{a}(23 \%)$.

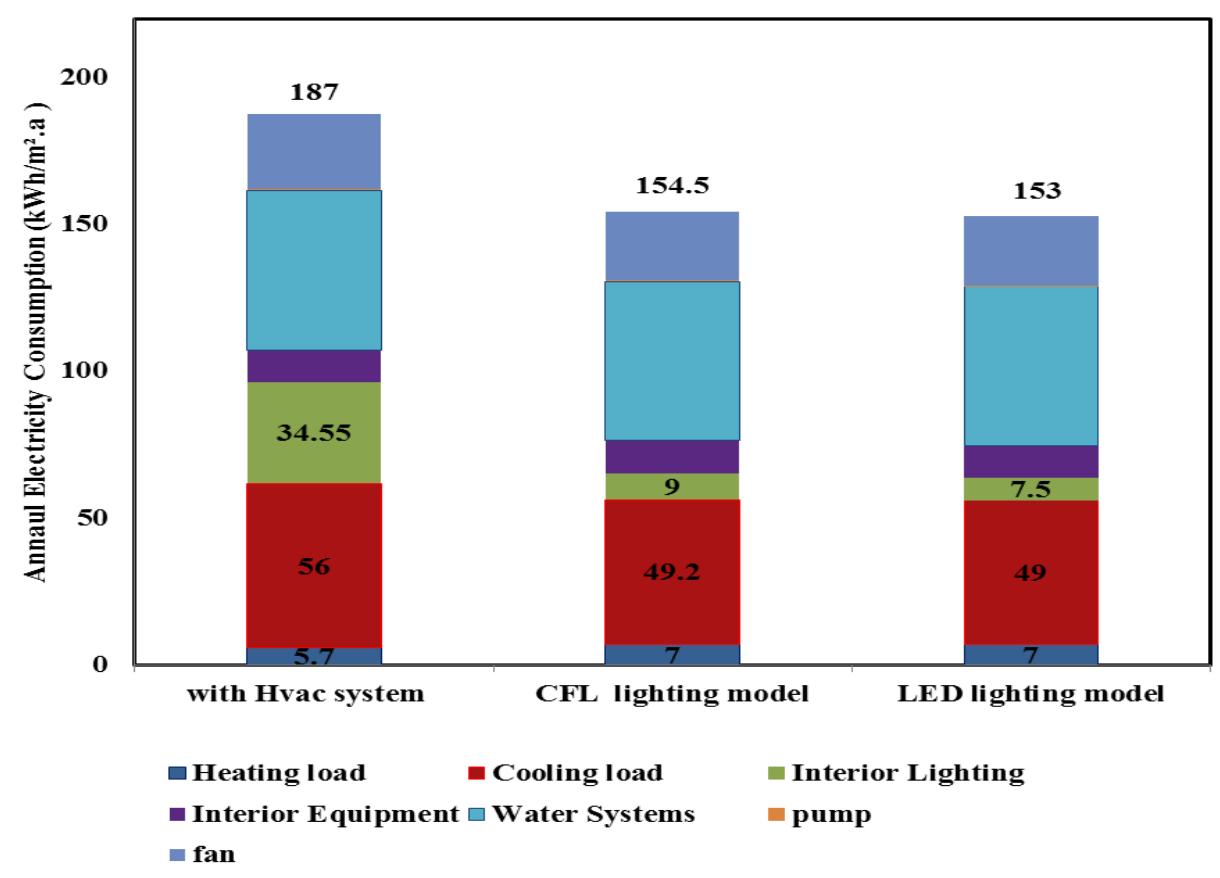

Fig. 17 Effect of lighting type on annual cooling and heating delivered

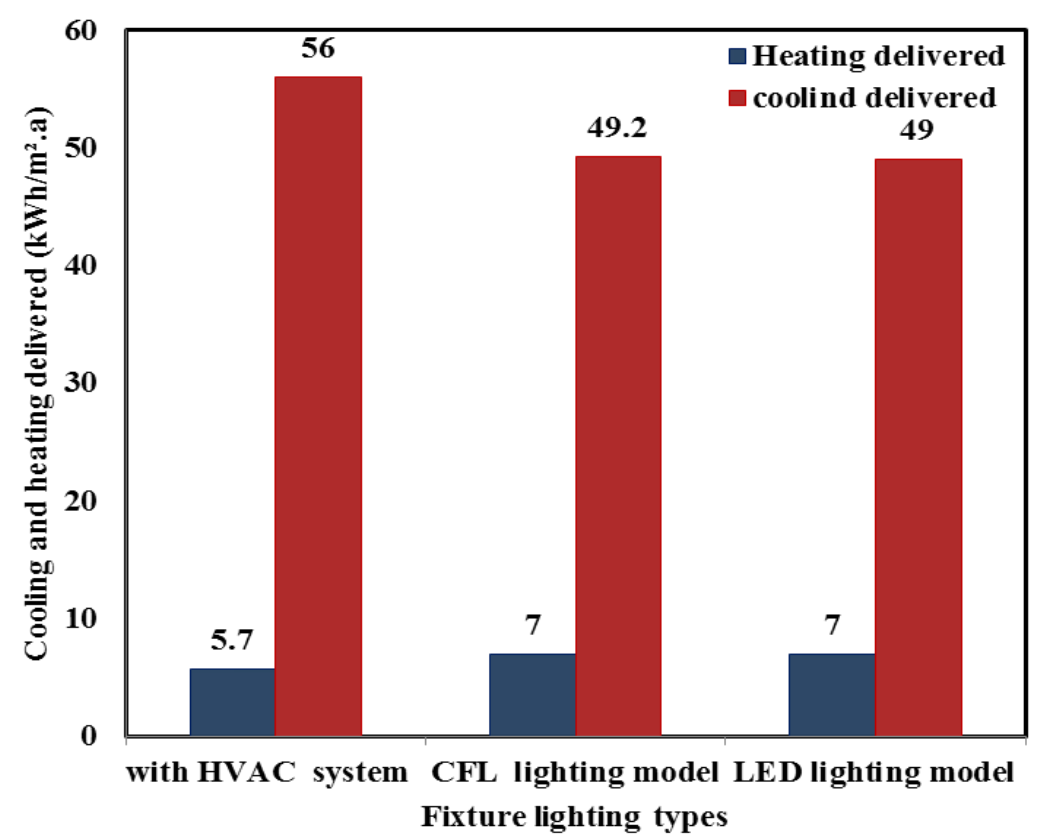

Fig. 18 Effect of lighting type on annual space cooling and heating delivered 


\subsubsection{Effect of all Energy Efficiency Measures}

Finally, the optimized model characteristics are based on the combination of the value of all implemented EEMs as follow using LED fixture lighting, adding the exterior wall insulation is mineral wool blanket with thickness $0.045 \mathrm{~mm}$; adding the external shading projection factor is equal to 0.9 and using glazing type is double glazing type with medium emissivity and minimum SHGC.

Fig.19 indicates the result of the optimized model that reach the best model where the total electricity decreases by $54 \mathrm{~kW} / \mathrm{m}^{2} . \mathrm{a}(29 \%)$ from the base case model. The lighting load decreases by $27 \mathrm{~kW} / \mathrm{m}^{2}$.a (78\%) where reaches to the minimum 7.5 $\mathrm{kWh} / \mathrm{m}^{2} \mathrm{a}$. Fig.20 shows the electrical cooling load demand decreases with $53.5 \mathrm{~kW} / \mathrm{m}^{2} . \mathrm{a}(41 \%)$ where reaches the minimum $76.5 \mathrm{kWh} / \mathrm{m}^{2}$.a. The electrical heating demand decreases by $1.5 \mathrm{~kW} / \mathrm{m}^{2}$.a $(23 \%)$ where reaches the minimum $5 \mathrm{kWh} / \mathrm{m}^{2} . \mathrm{a}$.

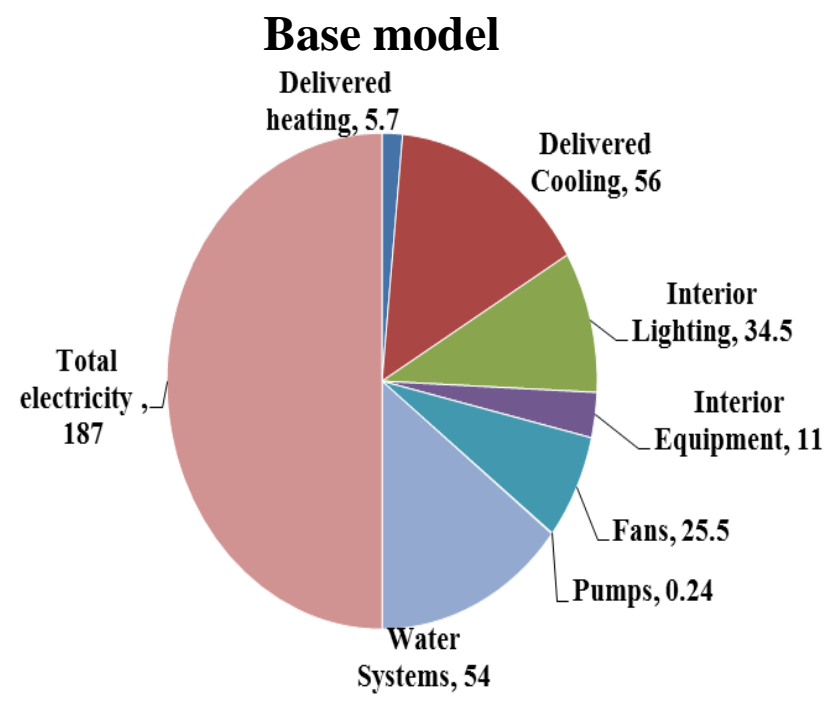

Optimization model

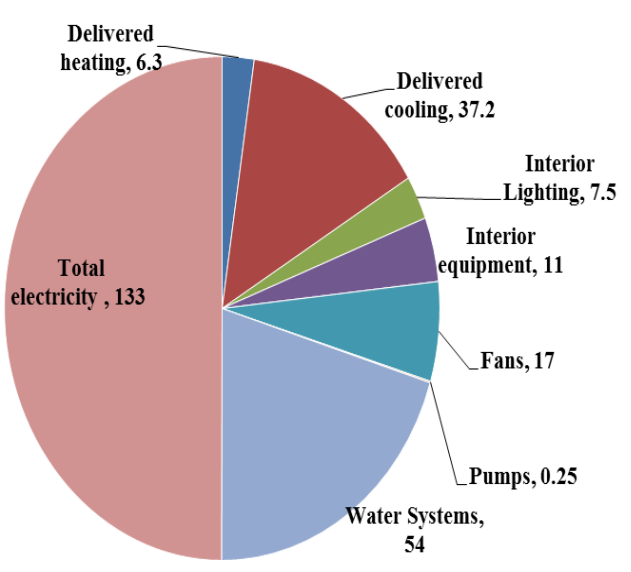

Fig. 19 Electricity break down for the optimized model and base case $\left(\mathrm{kWh} / \mathrm{m}^{2} . \mathrm{a}\right)$ 


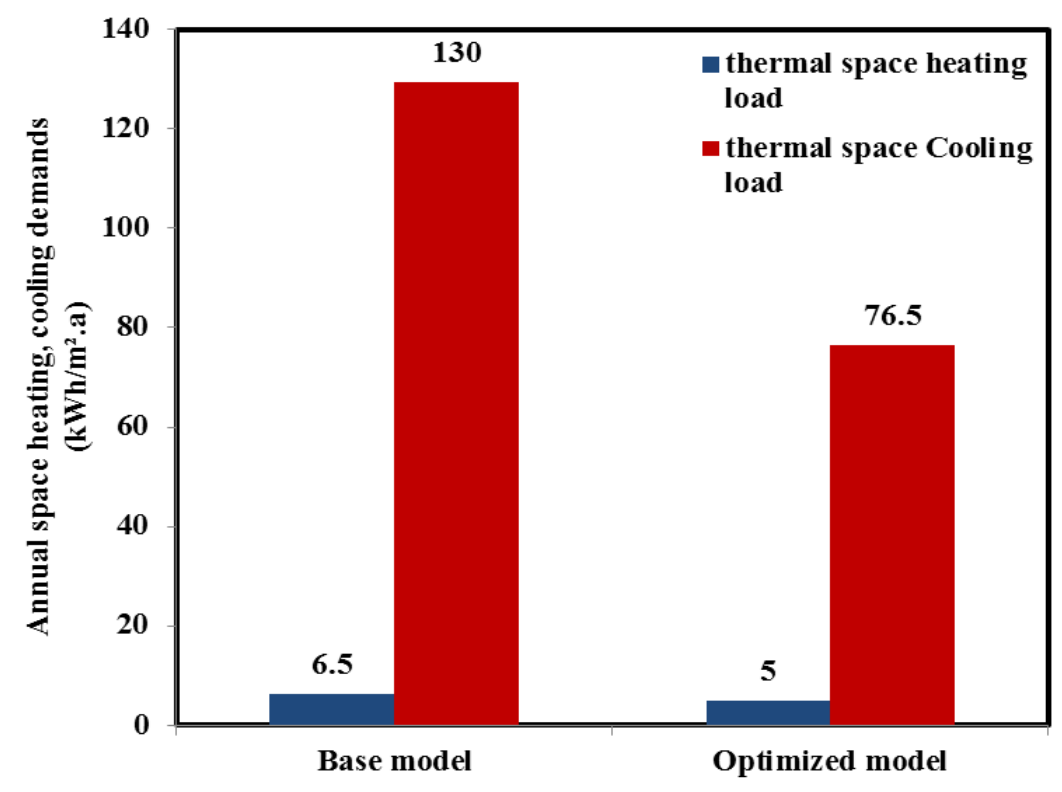

Fig. 20 Comparison between annual space cooling demand for optimized model and base case

\subsection{Conclusions}

The present work investigates the residential building energy needs in Egypt by implementing Energy Efficiency Measures (EEMs) under Cairo weather conditions using building simulation tool. The building simulation tool is Open-Studio software coupled by Sketch-up 2017 software and Energy plus software. The considered EEMs are adding external wall insulation, adding window shading, using efficient lighting fixture and selecting window glazing type. Based on the reported results, the following conclusions can be drawn;

-The annual thermal space cooling demand, heating demand and the total electricity consumption are $130 \mathrm{kWh} / \mathrm{m}^{2} . \mathrm{a}, 6.5 \mathrm{kWh} / \mathrm{m}^{2}$.a and $114 \mathrm{kWh} / \mathrm{m}^{2}$.a, respectively.

- Reducing the overall heat transfer coefficient of external wall by adding thermal insulation from $1.7 \mathrm{~W} / \mathrm{m}^{2} \mathrm{~K}$ to $0.58 \mathrm{~W} / \mathrm{m}^{2} \mathrm{~K}$ decreases the cooling and heating demands by $7 \%$ and $60 \%$, respectively.

- Adding shading by projection factor of 0.9 for all external windows decreases the cooling demand by $13 \%$. 
-Double glazing type with medium emissivity and minimum SHGC decreases the cooling and heating demands by $14 \%$ and $30 \%$, respectively.

- LED lighting type reduces the annual space cooling demand and electricity consumption by $17 \%$ and $27 \%$, respectively and increases the annual thermal space heating demand by $26 \%$.

- Electrical delivered cooling demand decreases by $19 \mathrm{~kW} / \mathrm{m}^{2}$.a $(34 \%)$ and the electrical delivered heating demand increases by $0.6 \mathrm{~kW} / \mathrm{m}^{2} . \mathrm{a}(11 \%)$ while the lighting load decreases by $78 \%$. 


\section{REFERENCES}

[1] Bataineh, K., Alrabee, A., Improving the Energy Efficiency of the Residential Buildings in Jordan, Buildings, 2018, 85, 1-16.

[2] U. S. Energy Information Administration International Energy Outlook, International Energy Outlook with Projections to 2040, Office of Energy Analysis U.S. Department of Energy, May 2016, www.eia.gov/forecasts/ieo.

[3] Egyptian Electricity Holding Company, Annual Report, 2016/2017, Ministry of Electricity \& Renewable Energy, Egypt, 2017, www.pccadvertising.com.

[4] Energy Efficiency Residential Building Code, ECP-306, Ministry of Housing, Utilities and Urban Communities, Housing and Building National Research Center, HBRC, Egypt, 2005.

[5] Energy Efficiency Non Residential Building Code, ECP-306, Ministry of Housing, Utilities and Urban Communities, Housing and Building National Research Center, HBRC, Egypt, 2005.

[6] Nassief, M. M., Evaluation of Electricity Consumption of a Residential Flat in Egypt, American J. of Electrical Power and Energy Systems, 2014, 3, 37-44.

[7] Aldali, K. M., Moustafa, W. S., An attempt to achieve efficient energy design for High-Income Houses in Egypt: Case Study: Madenaty City, International J. of Sustainable Built Environment, 2016, 5, 334-344.

[8] Salem, A., Ismaeel, W. S. E, Greening the Egyptian Building Code through Analysis of International Codes, Architecture - Urbanization Conference, 2016, 166-176.

[9] Hanna, G. B., Energy Efficient Residential Building Code for Arab Countries, Proceedings of the Tenth International Conference for Enhanced Building Operations, Kuwait, 2010, 1-7. 
[10] Hanna, G. B., Energy Efficiency Building Codes and Green Pyramid Rating System. International J. of Science and Research, 2015, 4, 3055-3060

[11] Alaidroos, A., Krarti, M., Optimal design of residential building envelope systems in the Kingdom of Saudi Arabia, Energy and Buildings, 2015, 86, 104117.

[12] Ahmed, A. N., Samaan, M. M., Farag, O. M. a., \& El Aishy, A. S., Using Simulation Tools for Enhancing Residential Buildings Energy Code in Egypt, 12th Conference of International Building Performance Simulation Association, Sydney, 2011, 1141-1148.

[13] Alghoul, S. K., Alrijabo, H. G., 2016, The Impact of External Window Shading on Energy Requirements of Office Buildings, Journal of Multidisciplinary Engineering Science and Technology, 2016, 3, 5994-5999.

[14] Samaan, M., M., Farag, O., Khalil, M.,2016, Using simulation tools for optimizing cooling loads and daylighting levels in Egyptian campus buildings, Housing and Building National Research Center Journal, 14, 79- 92.

[15] Raslan, R., Mavrogiann, A. I., Developing a National Stock Model to Support Building Energy Efficiency Research and Policy in Egypt, Building Simulation Cairo -Towards Sustainable - Green Built Environment, 2013, 1-12.

[16] Marzouk, M., Metawie, M., Framework for Sustainable Low-Income Housing Projects in Egypt, Computing in Civil and Building Engineering, 2014, 19601968.

[17] Kamel, E., Memari, A. M., Automated Building Energy Modeling and Assessment Tool (ABEMAT), Energy, 2018, 147, 15-24.

[18] Arambula, R., Naboni, E., Pernigotto G., Optimization Tools for Building Energy Model Calibration, 8th International Conference on Sustainability in Energy and Buildings, Italy, 2017, 111, 1060-1069. 
[19] Fumo, N., Mago, P., Luck, R., Methodology to estimate building energy consumption using EnergyPlus Benchmark Models, Energy and Buildings, 2010, 42, 2331-2337.

[20] Mustafaraj, G., Marini, D., Costa, A., Keane, M., Model calibration for building energy efficiency simulation. Applied energy, 2014, 130, 72-85.

[21] Reda, F., Tuominen, P., Hedman, Å., Ibrahim, M. G. E., Low-energy residential buildings in New Borg El Arab: Simulation and survey-based energy assessment, Energy Buildings, 2015, 93, 65-82.

[22] Attia S., Evrard A., Gratia E., Development of benchmark models for the Egyptian residential buildings sector, Applied Energy, 2012, 94, 270-284.

[23] Mahdy M., Nikolopoulou M., From construction to operation: Achieving indoor thermal comfort via altering external walls specifications in Egypt, Advanced Materials Research, 2013, 689, 250-253.

[24] Mahdy M., Nikolopoulou M., Evaluation of fenestration specifications in Egypt in terms of energy consumption and long term cost-effectiveness, Energy Building, 2014, 69, 329-343.

[25] https://www.wunderground.com/ website. 